\title{
TRIB1 Gene
}

National Cancer Institute

\section{Source}

National Cancer Institute. TRIB1 Gene. NCI Thesaurus. Code C119628.

This gene plays a role in modulation of MAP kinase-dependent signaling. 